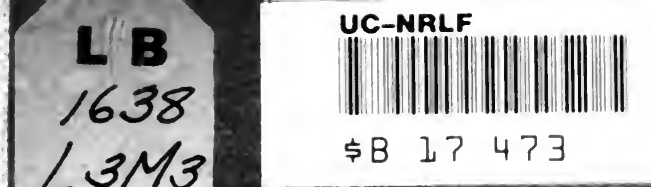

$\angle 3 M 3$ 


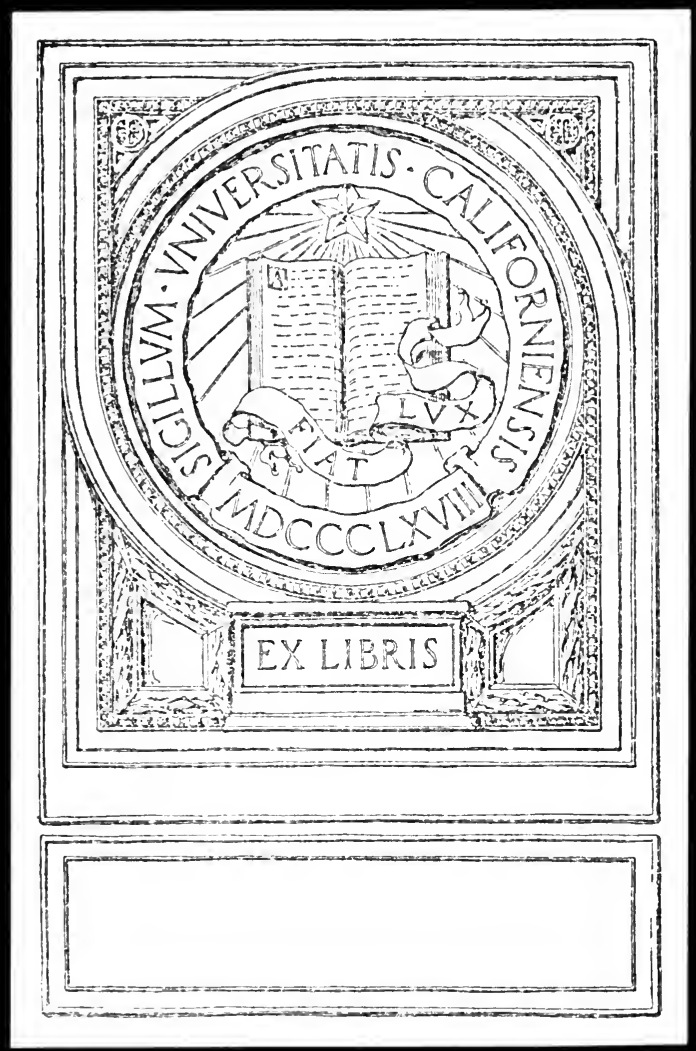




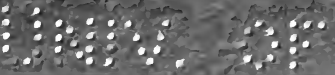

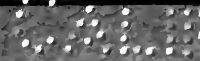 \\ THE CASE FOR LATIN IN SECONDARY SCHOOLS}

BY J. W. MACKAIL

PRESIDENT OF THE CLASSICAL ASSOCIATION

LONDON

JOHN MURRAY, ALBEMARLE STREET, W. 1922 
Digitized by the Internet Archive in 2007 with tunding from Microsefit Corporation 
THE CASE FOR LATIN IN SECONDARY SCHOOLS 
BY THE SAME AUTHOR

LATIN LITERATURE

THE ODYSSEY OF HOMER

Translated INTO ENGLISH Verse

VoL. I (Books i-viii)

VoL. II (Books ix-xvi)

VoL. III (Books xvii-xxiv)

All Rights Reserved 


\title{
THE CASE FOR LATIN IN SECONDARY SCHOOLS
}

\author{
BY J. W. MACKAIL \\ PRESIDENT OF THB Classical ASSOCiation
}

LONDON

JOHN MURRAY, ALBEMARLE STREET, W. 


\section{THE CASE FOR LATIN IN SECONDARY SCHOOLS}

THIs pamphlet is meant to set out, briefly and simply, for the use not merely of those engaged in organising, carrying on, and improving the work of national education, but of ordinary people, and particularly of parents, the case for Latin in Secondary Schools; that is to say, in schools which, as defined by the Board of Education, ${ }^{1}$ offer a course of general education suitable for pupils of an age-range extending from 12 to 17 at least.

Three points should first be stated, and must be borne in mind in order to make the scope of what follows clear :

I. What is dealt with here is the case for Latin. The case for Greek is a different thing, and is not dealt with here: it would only confuse the issue. For the same reason, the substitution of Greek for Latin as a subject in the Secondary School course, an experiment which has been advocated in some quarters, and has here and there been tried, is not discussed. "The classics" in the ordinary use of the term mean Latin and Greek, and therefore that term will not be used at all except where it occurs in quotations.

2. What is dealt with is Latin in Secondary Schools ; not in Universities and Colleges, or in other organisa-

1 Regulations for Secondary Schools, Chapter I, Articles I and 2. 
tions for the pursult of study by those who have left school.

3. Secondary Schools are schools both for boys and for girls. How far assimilation of curriculum as between boys' and girls' schools should be carried, and whether it is not in fact carried too far, are questions of great importance, on which there is much difference of opinion; but they fall quite beyond the scope of this discussion. Where the word "boy" is used here, it is to be understood as meaning "boy or girl" in so far as the education of boys and girls is organised on the same lines and follows in substance the same curriculum. It is taken for granted that, with both sexes alike, the object aimed at by education is equipment and preparation for a life of full citizenship.

\section{THE CASE IN SUMMARY}

The case for Latin in Secondary Schools may be put shortly thus :

I. What a Secondary School should provide for its pupils is a large human education, its object being so to develop and discipline their faculties that they can be used to the best purpose, for themselves and for the community.

2. Latin is an element of high value in such an education ; and without Latin, however good it may be, it is not as good as it might be.

3. Latin therefore ought not only to be placed within the reach of those pupils who for special reasons want to learn it, but to be an element in the course which the whole body of the pupils normally pursue. 
4. That this ought to be done means that it can be done.

This is the case which is developed more fully in the following pages.

\section{THE FUNCTION OF THE SECONDARY SCHOOL}

Secondary Schools are the pivot of education. Where our national system failed until a generation ago was that, where there ought to have been the pivot, there was a gap. Before the Industrial Revolution, there had been a coherent system so far as it went; but it only applied to the small proportion of the nation who had opportunity of access to it, or who were able and willing to pay for it. More than fifty years ago, the idea of an educated nation was created. By a series of Acts of Parliament from 1870 onwards, free elementary education was provided for all children, and the duty of making their children receive it was imposed on all parents. During the same period, large provision was made for advanced education by the foundation of Provincial Universities, Colleges, Technical Institutes, and the like. But it was not until the beginning of the present century that we began to plan out and provide a system of Secondary Schools. Towards this provision, all the material available in the way of existing schools was utilised. But in order to be recognised as Secondary Schools by the State, both existing and newly founded schools had to provide for all their pupils (as well as physical and manual training, music, drawing, and for girls, needlework and some elements of housecraft) a course which included (I) English Language and Literature, (2) at least one 
language other than English, (3) Geography and History, (4) Mathematics, (5) Natural Science. ${ }^{1}$

What was meant to be secured was a due combination for the pupils of the two sides of education which are called (for fault of better words) humanistic and scientific. The purpose was to lay broad and solid foundations for full citizenship, by making the pupils able to express themselves in speaking and writing and to understand the spoken and written language of others ; by giving them some knowledge of the world on which they live and of what has happened in it; and by initiating them into the processes and laws of nature. Throughout, the object aimed at was not only to impart knowledge, but to create the love of knowledge ; to train intelligence; to quicken and enlarge interest; and to develop the imagination by which knowledge is made living and fruitful.

\section{CONFLICTING CLAIMS}

Between the so-called humanistic and the so-called scientific subjects there is no real opposition. The conflict between their claims which was once acute has now almost ceased to exist. It is recognised that both are alike essential to a well-ordered education, and not only so, but that each is the complement of the other and reinforces its value. All the dispute that now arises is as to the amount of time to be allotted to one or the other out of a total number of school-hours, which tends for various reasons to diminish. Geography and History are

1 Regulations for Secondary Schools, Chapter II, Articles 7-9. That chapter also allows certain modifications, in particular cases, of the general rules laid down. 
subjects which may be called either humanistic or scientific, and which ought to be both. Even for language teaching, scientific method is indispensable. But in the field of the humanities another rivalry has arisen, particularly as regards that part of the field which is concerned with languages. It is here that the place to be assigned to Latin comes into question.

\section{LANGUAGE}

Language, and what is expressed in language, is, from a strictly practical point of view, the most important of all the subjects of education. Language is the vehicle of all thought, and the motive force towards all concerted action. Without it, we should be helpless; without an adequate mastery of it, we are almost powerless ; without appreciation of it, we are cut off from the highest pleasures of the mind. Language is in the first place an art, and one which we all have to practise. It is in the second place an instrument, and one which we all have to use. It is in the third place a key, which opens to us the doors of all knowledge, and enables us to enter into the whole inheritance of our race.

English is our mother tongue: English literature is our common heritage. To be able to speak and write English so as to express our meaning clearly and exactly, to be able to read English intelligently and appreciatively, is the first object in our education. But it is generally agreed that language teaching in Secondary Schools should not be confined to English unless in quite exceptional cases. In fact, we hardly call anyone an educated man or woman who has no knowledge of any language beyond the mothertongue. Partly, this is a matter of practical useful- 
ness. Many, though not most, people will have occasion to use, and some will be obliged to use, one or more foreign languages in the ordinary course of their grown-up life. Not to have the power of speaking and writing, and still more, not to have the power of understanding, any other language than our own is therefore a distinct loss ; and French, as the most important for many purposes of other European languages, is as a matter of fact taught in practically all our Secondary Schools. But there is another reason, of still more importance. It is this : that the feeling for language as such, and the power of using our own language accurately and effectively, are both immensely increased by knowing more languages than one. Indeed, to get a grasp of the principles of all language and a full control of our own, it is very desirable to learn not only one but two languages besides English. Latin has special claims to be one of these.

\section{THE IMPORTANCE OF LATIN FOR ENGLISH}

English is a language of mixed origins, an alloy made up out of several elements. The Latin element in it is not only very large in amount, but of great importance in giving it its quality. It has been estimated that of the 100,000 words or thereabouts in the current English vocabulary, no less than 60,000 are of Latin origin, as against 30,000 purely English, and 10,000 derived from other foreign sources. ${ }^{1}$ The Latin element in English literature is of corresponding importance. It was by receiving and assimilating the Latin influence that English grew from a provincial dialect into a world-language, from

1 West, Revised English Grammar, p. 15. 
an insular into a universal literature. The structure of English prose is in substance that wrought out and given permanent form by the great Roman writers. English poetry, from Chaucer down to our own day, has likewise developed under the direct, as well as the indirectly transmitted, influence of the Latin poets who created a standard and left a model for the civilised world. To gain any historical grasp of English language and literature, Latin is admittedly necessary. Even in familiar daily usage, our speech has embedded in it scores of Latin words and phrases which have become almost parts of the English language. Further, Latin by its logical precision is invaluable towards forming a habit of clear thought, and towards enabling people not only to think clearly, but to express their thought accurately, in English. The claims of Latin to a place in schools are often, and quite reasonably, urged on the ground that it is the common source from which French, Italian, and Spanish are derived, and that accordingly a knowledge of Latin puts one in the way of learning these languages, or any one of them, quicker and better. That is so. But it is still more important to realise that for the study and mastery of English alone, Latin is all but indispensable.

\section{THE FALLACY OF COMPULSION}

Objection is raised to Latin as a subject of the normal course in Secondary Schools on the plea that Latin should not be compulsory, and that this would give Latin some sort of privilege or monopoly. The word " compulsory" is invidious, and is meant to be so. What is claimed here for Latin is, not that it should be compulsory, but that it is essential. No 
monopoly, no special privilege, is claimed for it : it stands on its merits. The case for it is, that it is of such high educational value for all kinds of pupils as not merely to justify, but to call for, a place in the curriculum followed by the school as a whole, up to the point at which the pupils can properly begin to specialise. The contention that Latin is a proper and useful subject for pupils who have a turn for it, but not for the majority who have not a turn for it, is specious. But it involves the dangerous fallacy that education is not a discipline, but should follow the line of least resistance ; it means premature specialisation in its most insidious form. The Modern Languages Committee's Report ' lays down that those pupils who " elect and are permitted " to learn Latin should be pupils of marked capacity for languages ; as if the whole object of a Secondary School were not to develop and train this capacity, among others, in the whole body of its pupils. "For good Latin," that Report goes on to say, " a considerable sacrifice is not too great ; for bad Latin even a small sacrifice would be excessive." No doubt : but what is the relevance of this truism? and why confine it to Latin? The notion of " sacrifice " must be obliterated before the Secondary School fulfils its aim and function. Where we are convinced that any subject, whether humanistic or scientific or both, is of essential value towards large realisation of human capacity, towards opening the doors widely upon the world of people and things and fitting the boy or girl to proceed into it, we shall not speak of that subject as compulsory, except as we may speak of compulsory light and air, or of compulsory health.

1 Report, paragraph II 6 


\section{THE ALLEGED UNDUE PREDOMINANCE OF LATIN}

The belief that "the dead languages" dominate education in England lingers here and there; it must be mentioned, in order to set the facts in their true light. It is said, with truth but with little relevance, that under the old Public School tradition boys spent nearly all their time at school, from early childhood, on Latin and Greek. But that tradition is a thing of the past. Even in schools like Eton and Winchester, where the classical tradition is strongest, only about one-third of the school hours are allotted to Latin and Greek except in those top Forms which specialise on Latin and Greek, as other Forms do on Mathematics, or Science, or History, or Modern Languages. ${ }^{1}$ The complaint, so far as facts justify it, only applies to Preparatory Schools which are run as nurseries for the Public Schools. In some of these it may still be true that " the main business of life is the Latin Grammar." " But in the great mass of the Secondary Schools, Latin, so far from being unduly dominant, has a very precarious footing. In a good many of them, there is no provision for it at all, and no teacher capable of teaching it ; in the large majority, it is only an alternative subject, with little time allotted to it, taken by a few pupils, and even by them often dropped before any substantial progress has been made with it. But the same people who, from ignorance or prejudice, assert that Latin bulks too largely in the course of education given in Secondary Schools, often go much farther. They say that Latin has no place in a

1 Prime Minister's Committee's Report on the Classics, Appendix G.

2 Sir R. Rodd, Speech at the formation of the Parents' Association, February 14, 1922. 
practical education; that it cannot be learned without injury to other and more important subjects; that it is neither necessary nor desirable except for the few pupils who will specialise in it, and continue its study after they leave school ; and that for the vast majority of pupils a little Latin is useless, and enough to be useful is impossible. These are the claims or assertions, sometimes expressly made, sometimes implied or taken for granted, which must be examined.

\section{PRACTICAL EDUCATION}

Most parents would say that what they want for their children is a good practical education. But few of them have ever really tried to think what this is. They are ready enough to complain that their children are taught useless subjects ; but if pressed to explain, they cannot say what it is they mean, still less what it is they want. They are apt to forget that the object of school is not to produce a " finished article " for the market, but to train and bring out capacity; to form the habit of steady work, the sense of accuracy, the desire and respect for knowledge ; to teach the love of learning and the way to learn.

"Practical" means bearing on practice-that is to say, on the conduct of life. Part of the conduct of life is ability to make a living by doing productive work, or taking part in the machinery of an industrial and commercial community. But another part, as important, is to live interestedly and intelligently; to understand things; to know what is good and prefer it to what is bad. Unfortunately the word "practical" is often used in quite a different sense, 
and subjects are called practical which have, or are thought to have, some immediate cash return, by enabling the boy or girl to become a wage-earner sooner or at better pay. The result has often been that, for the sake of this immediate return, or rather on the chance of it, education has been sterilised. It has failed to bring up citizens; it has turned out low-grade machines for doing low-grade work. The three R's are practical, because in a civilised community they all have to be practised daily by everybody. Outside of them, the only practical subjects of a school course, in the real sense, are those which make the pupils into better human beings, develop their intelligence and character, make life richer and more interesting for them, teach them to value and understand themselves, their fellow-men, and the world in which they live. They are practical in the measure to which they do this. As Mr. G. Sampson very truly says in his plea for a humane system of national education," "I urge that all children shall have a practical education that will fit them for their station in life.... Their station in life is to be citizens of the Commonwealth ; there is none higher, and none lower.... The lift-man would work his switch no worse if he were quite illiterate, and no better if he were a Doctor of Science. It is not as a lift-man that he is worth educating, but as a man."

\section{WHAT IS THE USE OF LATIN ?}

This is a question which is often asked, and often asked in a way which implies that the answer is, " Little or none." Defence of Latin has even sometimes been based on the paradox that its use is its

1 English for the English (Cambridge University Press, 1921). 
uselessness ; the meaning implied being that, from its being useless, it sets up a sort of ideal of knowledge pursued for its own sake. In this fallacious argument, as in all widespread fallacies, there is an element of truth, namely, that knowledge is an end as well as a means. Knowledge is power, even if that power be of a kind that is not or cannot be directly exercised. But as to this, Latin is just on the same footing as all subjects except those which are, like typewriting or dressmaking, directly vocational. The boy when he leaves school cannot sell his knowledge, such as it is, of Latin ; but no more can he sell his knowledge, such as it is, of geography or chemistry. What he can sell is the capacity, the awakened and trained intelligence, that education has given him. Whether he sells it or not, it has become and remains his possession.

But this is a very abstract way of looking at the question; we must get at the facts more closely. First, a few testimonies may be cited; it would be easy, if space allowed, to multiply them tenfold.

Mr. Leaf, a former President of the Institute of Bankers and Chairman of the London Chamber of Commerce, says, "After a life's experience, in my opinion there is no better training than the classics for a man who hopes to go far in business." 1

This bears out the statement of the Prime Minister's Committee on the Classics: "The witnesses who supplied us with evidence were representatives of engineering, shipping, scientific industry, commerce, and banking. They were unanimous that a classical education was of the highest value, and that from their point of view classics should be included in all Secondary School Curricula up to the age of 16 or $17 . "$ "

The same testimony was given with equal emphasis

1 Proceedings of the Classical Association, I921, p. 21.

2 Report, p. 255. 
by leading men in the United States, including business men, lawyers, doctors, engineers, etc., and has been collected in a very interesting volume, which is well worth reading by all who want further evidence. ${ }^{1}$

Sir Wilmot Herringham, Consulting Physician to the Forces in France throughout the late war, at the Conference of Educational Associations in December last, made two further points: "If the study of literature were to be diminished it would be a great loss to the nation, and there is no such introduction to the study of literature as the study of the classics " ; and, "There could be no greater loss so far as art went than the loss of the classical education."

To this may be added the words of a teacher of History in the University of London: "Latin is an invaluable means of mental training, and an indispensable tool for advanced work in Language, Literature, and History. University teachers of History constantly complain that their students lack a sound knowledge of Latin. They have certainly learnt much more modern history at School ; but I would rather they came up to college with less actual knowledge and more vigorous minds." These remarks bear a wider application. They apply not only to University studies, but to the studies and pursuits of ordinary life. The point can hardly be put better than it has been put in the following words :

" Latin must be kept in schools, because it is the greatest training that the boy can go through. The average boy's mind is a pigsty; he has got to be taught what connected thinking is, and Latin is the only instrument that will do that; I am not going to throw over Latin for anything in the world." "

These are the words of a teacher whose own

1 The Value of the Classics (H. Milford, 1917).

2 Proceedings of the Classical Association, 1921, p. 47 
subject is not Latin : and this ts the great use of Latin.

But perhaps there is one still greater, if we consider what "use" really means. In a very real sense, the most useful things in the world are those which give the greatest amount of the highest joy. As to this, one cannot better the words of Mr. Sampson in the volume already cited. He has been speaking, in terms with which all Latin scholars must entirely sympathise, of a " cant of the Classics," and denying -perhaps rather superfluously, for no rational person affirms it - that it is only through Greek and Latin that humane education can be given. Then he goes on: "For some, for a few, the Greek and Latin languages are the gates that open immediately into Paradise." I have given the sentence in full, that there may be no suggestion of garbling his words; but now it may be repeated so far as it bears on this discussion. "For some, for a few, Latin is a gate that opens immediately into Paradise." So far as these few are concerned, any question as to the use of Latin is answered before it is asked. But why should they be few? What right have we to assume that any boy or girl in a Secondary School is not one of them? Why, but from lack of faith in human nature, and the superstition of an irredeemable and ineducable proletariat? Is it not our duty to see that they shall not be few, but many? Latin, we are told, is proper enough for those who have capacity for it. Do we teach reading and writing only to a few children in whom, by some superhuman instinct, we have ascertained capacity to read and write? Do we teach the multiplication table only to those who have shown capacity for figures? Quintilian, the great Latin writer on education, knew better than that: to cut down education, he says, to the assumed scope of the pupil's capacity is treatment 
only fit for mental defectives. The case for Latin in the Secondary School, at its highest issue, is that the gate should be opened wide; that Latin, once a rare luxury, should be made a common possession ; that education so far as it is carried should be for all who share it, not only good (as it can be without Latin) but the best.

\section{OBJECTIONS TO LATIN}

It is time now to set out the arguments used against making Latin a subject in the ordinary curriculum of Secondary Schools, so as to see what they really amount to. The two which bulk most largely have already been touched upon. They are, that Latin is useless, and that Latin is an elegant luxury. Both of them are profoundly untrue. As to the first, it has been shown that Latin is one of the most practical subjects that a school course can include. The second seems to be based on some queer notion, either that Latin is something of which there is not enough to go round, and which therefore must not be shared among more than a few ; or else, that it is something the whole value of which, like that of a used postage-stamp, consists in its rarity. But beyond these, there are more definite objections urged. They are pretty nearly all included in the following list :

(I) Latin is a dead language.

(2) It is the hall-mark of a social class.

(3) There is not a supply of competent teachers.

(4) Boys don't want to learn it.

(5) Those who begin it will seldom keep it up.

(6) There is no room for it in an already overcrowded time-table. 


\section{Latin is a Dead Language}

What this means is, that Latin is not a language which people, either in England or in other countries, now speak or write as their ordinary means of communication. But the word "dead" is so used as to imply, not that the people who spoke and wrote Latin are dead, but that their writings, and the records of their thoughts and acts, are dead matter ; that they have only an antiquarian interest. This is not true. They are as much alive, as vital, and as powerful as ever. Nor does this hold good merely of the writings of Virgil or Horace, of Livy or Cicero. The Latin language itself, no less than the masterpieces written in it, is one of the greatest works of human art. To speak of them as a dead language and dead books is like speaking of the Elgin marbles as dead sculpture, of the work of Titian or Velasquez as dead painting, or of Bach's B Minor Mass as dead music.

\section{Latin is the Hall-mark of a Social Class}

This is precisely the vice in national education which must be got rid of so far as it may still exist. Treated as the hall-mark of a social class, as to some extent it once was, Latin was not only a dead but a death-dealing subject. What is urged is that it should cease wholly to be that; that it should become as widely as possible, without distinction of class or wealth or occupation, a national possession. Baths, windows, all the decencies of life, were once the hall-mark of a social class. If anything is good for the enrichment of life, why should people be suspicious about sharing it? Why should they keep away from sources of enlightenment and joy because those sources used not to be within their 
reach ? The accredited representatives of Labour are sound here. They stand for " adequate instruction in Latin for every boy or girl who is qualified to profit by it," 1 and this means a course of Latin in all the Secondary Schools, to which in greater and greater numbers the pick of their children go ; for all these children are certainly qualified to profit by it.

\section{There are not competent teachers.}

This is true; the supply is inadequate both in quantity and in quality. It must be made adequate. All those concerned with the study of Latin in England would agree with Dean West, the President of the American Classical League, when he says, "The one problem which now gives us most concern is to learn wherein the quality of our teaching is poor, and to devise measures of improvement." But if we keep Latin out of the Secondary Schools because of this difficulty, we shall only aggravate and perpetuate the difficulty. Latin, like anything else, must be learned before it can be taught. If it is not taught widely and largely throughout the Secondary Schools, we shall never get even the raw material of men and women competent to teach it.

- This is no new problem. When science was introduced, and later when modern languages were introduced, into the ordinary Secondary School curriculum, there was exactly the same difficulty. In the abstract, the conclusion is that, as no subject can be properly taught by those who have not learned it well, and as no one can learn a subject properly without being taught it well, all education is condemned to immobility. It is the old sophistical argument to prove that motion is impossible. The answer is, in one of those pointed Latin phrases

1 Prime Minister's Committee's Report on Classics, p. 2 I. 
which have become part of our own language, Solvitur ambulando. Education, like other things, does move. Progress may be and must be slow, but with enthusiasm and patience it is certain. As has already proved the case in our schools with French or with physical science, each successive schoolgeneration will be better taught, and will produce in due time better teachers. The first years will be difficult, and may seem disappointing. But each year will mark progress, and the progress will each year be at a quicker pace.

\section{Boys do not want to learn Latin.}

The answer to this is, They do. It is of course true that in a sense boys do not want to learn anything. They are sent to school: they do not, ordinarily, run away from home against their parents' wishes or orders to go to school because of their insatiable thirst for learning. But if it is a good school, they enjoy learning. It is their job : if they grumble over it (as, being human, they will grumble over their job, whatever it may be, in later life), they like it all the same. They feel the satisfaction of knowing things, of becoming able to do things, of feeling their own powers. If this objection, then, means anything, it means that boys find Latin in some way peculiar to itself disagreeable. This is not so. Boys ordinarily take to Latin, unless it is very badly taught, with real interest. They feel, indistinctly, that it is an opening into a new region; they taste in it, often for the first time, the pleasure of exact thinking and the joy of doing hard things successfully. Many teachers vouch. for it that interest and proficiency in other subjects of school work is notably increased when Latin is begun. 
5. Most boys who begin Latin at school will drop it when, or before, they leave school, so that the time spent on learning its elements is mere waste.

This is perhaps the commonest objection. It is so irrational that some special reason must be sought for its prevalence. And one reason at least is not far to seek. It is to be found in the absurd grounds on which Latin as a school subject (or more generally, a classical education) has often been recommended. A picture is drawn of the accomplished scholar, and people are asked to believe that this brilliant creature is the normal product of a school in which Latin and Greek are taught. Naturally, they do not believe it, because it is obviously untrue. Many of the pupils will forget most of the Latin they have learned at school ; few will carry it farther; not one in a hundred, perhaps, will take it up as a specialised study. But that is not the point. Nobody urges that mathematics or science should be discarded from the Secondary School curriculum because most of the pupils will not keep them up, much less proceed farther with their study, afterwards. These subjects as taught in school do not turn out accomplished mathematicians or chemists. Very few of the pupils will have occasion in ordinary life to solve a quadratic equation or to analyse a chemical compound. Much even of the little they have learned will gradually fade away from them. But that does not mean that education has been wasted on them. What they have been taught has trained their minds, has awakened their powers, has given them keys to knowledge and shown them how to acquire it. And this holds good of Latin with equal truth.

Further, even a little Latin leaves something definite and permanent behind : this must be taken on trust 
by those who do not know it from their own experience. An Ode of Horace, or half a dozen lines of Virgil, or even a single Latin sentence in which some human thought or experience has found once for all its most perfect expression, will keep its value through life even if it be only a dimmed memory.

\section{There is no room for Latin in a time-table which is already overcrowded.}

This is a practical point to raise. But it is one which concerns school authorities themselves, and is too technical for detailed discussion here. It is a matter of conmon sense working on broad and clear views of the aims and objects of education. No time-table ought to be overcrowded. If it is, there is something wrong with it, that ought to be and can be put right. Head Masters and Head Mistresses can solve the problem; many have done so with great success. To construct a time-table, intelligence and even imagination must be applied. Too often it is a hand-to-mouth piece of work, or a thing of shreds and patches. The fault, in many schools, is timidity. They try to get in a little of everything, without sufficient regard to the course as an organic whole, to the quality of what is taught and the method of teaching, and to the relation of one subject to another. The more that the unity of all knowledge, the convergence and mutual reinforcement of all the elements of a liberal education, is realised, the easier it is to adjust them. Systematic work is being done in the planning. of one-year and three-year Latin Courses so as to secure the best combination of economy of time with solid grounding and effective progress. Model time-tables have been framed which are very useful for suggestion. But each school must work out a time-table for itself; and no time-table need 
or should be stereotyped. Elasticity must be preserved; the principle of growth must be kept in view. Both may be secured, if the whole course of education provided is always thought of as a living organism, not as a jigsaw puzzle with pieces that will not fit in. It must be remembered too, that for learning many things (such as commercial subjects) there are ample facilities after leaving school, and that they can be easily and quickly learned, when occasion arises, by anyone who has been through the training of a good Secondary School course. But Latin, if not learned at school, will probably never be learned at all; what it gives will have been missed for life.

\section{THE DOCTRINE OF SUBSTITUTES}

It is claimed by some, who do not deny the value of Latin and the importance of the Latin civilisation, that all that is useful in Latin can be got from English translations of Latin authors and from hand-books of Roman history. This is the greatest mistake of all. The use of hand-books is to give a sketch of a subject as a guide towards studying it. The use of translations is partly to help towards understanding the originals, partly to excite interest in the originals and a desire to know them. They are useful aids, but are no real substitutes; to know something about Latin by means of them is not to know Latin. The Latin masterpieces are works of art, in which the form and the substance are inseparable. But likewise (this is a point not enough realised) the Latin language itself is a work of art ; in many of the qualities of the highest kind of human language it is unsurpassed, in some it is unequalled. To know 
even its elements is to have got a mastery not to be got otherwise, of the structure and quality of language itself.

Without learning Latin, it is impossible to understand Rome, and the Roman civilisation on which our own world is based and by which our own citizenship was created. Without learning Latin, it is impossible to enter into the strength of Roman character, the solidity of Roman thought, and the precision of Roman language.

There are no substitutes, and no short-cuts. When Ignorance in the Pilgrim's Progress comes down the little crooked lane from the Country of Conceit into the Highway to the Celestial City, and Christian asks him, "How do you think to get in at the gate, for you may find some difficulty there? You came not in at the wicket-gate that is at the head of this way," he is very confident in his answer. "I hope all will be well," he says ; " and as for the gate that you talk of, all the world knows that that is a great way off of our country. I cannot think that any man in all our parts doth so much as know the way to it ; nor need they matter whether they do or no, since we have, as you see, a fine pleasant green lane, that comes down from our country the next way into it."

"It pities me much for this poor man," Christian says when they have parted with him; "it will certainly go ill with him at last." And so it did.

\section{WHAT IS PRACTICABLE?}

Some people, themselves brought up in the oldfashioned Public School tradition under which Latin was begun at the age of 7 or 8 , and continued, with 


\section{IN SECONDARY SCHOOLS}

the addition of Greek, as the staple of education for ten years or more, still hold that anything short of this is so inadequate as to be useless. Others, noting that extravagant claim, and seeing its extravagance, conclude (quite reasonably on the premises) that to learn Latin for a few years only and then drop it is mere waste of time. The conclusion is correct, but the premises from which it follows are false.

What is the least amount of Latin that is of any use is a point on which there are differences of opinion. In the present writer's opinion, it can hardly be put too low; always provided that the teacher is himself a competent scholar and knows what scholarship is. In the hands of such a teacher, Latin is a live thing. He will make it a live thing to his pupils, not by the amount but by the quality of what he teaches them. It cannot be too often repeated that the best quality of teaching power is most needed for beginners. By the intangible influence of his own personality and conviction, the good teacher will not only awake the intelligence, but excite the interest and imagination of the pupils. A year of Latin so taught not only may be, but is, of very great value.

But what is claimed as quite possible and as in every way desirable is, that the normal curriculum for the whole school should include a three-year, or preferably a four-year, course in Latin, It would ordinarily be begun at the age of I I to I2, and carried on up to the First Examination Stage. In the first year there would be a daily lesson, however short; and afterwards, not less than three, and if possible four, lessons a week. After the first year those pupils, if any, who showed complete incapacity could be switched off. With really good teaching, these would be few or none. Even for them, the time spent will not have been wasted; it will at 
in later life the masters and not the slaves of their work. Parents are realising this more and more. They want the best for their children. They wish their boy or girl to be able not merely to earn a living, but to live. Local authorities and school governors are honestly anxious to make their Secondary Schools as good as possible. Parents, if they see for themselves that a school is a good one, are mostly very willing to accept the course of education it provides, and leave its planning to those whose business it is. Boys and girls in a good school do the work they are set to do, without asking why; and they enjoy doing it.

\section{SUMMARY}

To recapitulate :

I. The object of a national provision of Secondary Schools is to supply, and to place within reach of all classes of the nation, an education up to the age of 16 at least, and up to the age of 17 or 18 so far as practicable, such as will prepare and equip them for:

(I) Advanced study, pursued by them no longer as schoolboys or schoolgirls but as students.

(2) Intelligent interest in, and power of dealing with, men and things.

(3) The privileges and responsibilities of citizenship.

(4) The realisation of their full human capacities.

2. Such an education, being directed towards formation of character in trained habits, and mobilisation of capacity for practical use, must lay its foundations largely, and not hurry for premature results. 
It must at once guide and follow the natural growth of the faculties, by supplying them with the best food and putting them through the best exercises. It must teach the pupils to know the difference between good and bad work, and to feel the joy of good work, whether their own or that of others. It must train them not only to work but to think, and to be able to express their own thought and understand the thought of their fellow-men.

3. This education may be very good, may very largely attain its purpose, without Latin. But with Latin it is better, and attains its purpose more certainly.

4. Latin as an integral element in the Secondary School course does not mean a disturbance, but a tuning-up and reinforcing of the whole work of the school. So far from there being any hostility between Latin and English, or Latin and French, or Latin and Science, all these subjects, Latin included, can be better taught and better learned as elements constituting an organic whole. As this is grasped and carried into practice, many of the difficulties that are the despair of teachers, the annoyance of parents, and the stumbling-block of pupils, will disappear of themselves. 

,

$x$ 


\section{UNIVERSITY OF CALIFORNIA LIBRARY}

BERKELEY

Return to desk from which borrowed.

This book is DUE on the last date stamped below.

\section{JAN $\& 1948$}

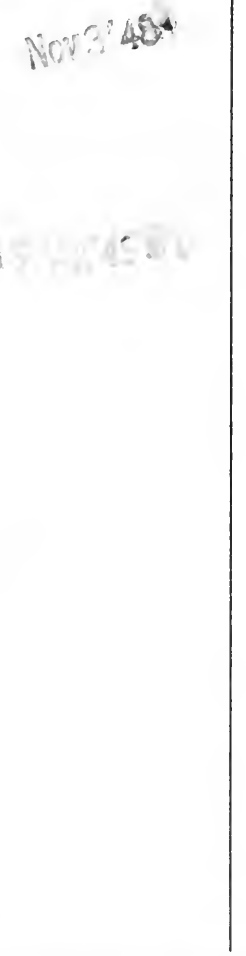


Pamph Baylord

make

Syracuse,

PAI. JAN 2

UNIVERSITY OF CALIFORNIA LIBRARY

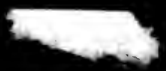

$50211 !$ 
